\title{
Changes in food and nutrient intake of 6- to 17-year-old Germans between the 1980s and 2006
}

\author{
Anna Stahl ${ }^{1, *}$, Claudia Vohmann ${ }^{1}$, Almut Richter ${ }^{2}$, Helmut Heseker ${ }^{1}$ and \\ Gert BM Mensink ${ }^{2}$ \\ 'Department of Nutrition and Consumer Education, University of Paderborn, Warburger Straße 100, D-33098 \\ Paderborn, Germany: ${ }^{2}$ Department of Epidemiology and Health Reporting, Robert Koch Institute, Berlin, Germany
}

Submitted 16 July 2008: Accepted 21 November 2008: First published online 23 February 2009

\begin{abstract}
Objective: To compare the food consumption and nutrient intakes of German children and adolescents in the 1980s with present dietary habits.

Design: Two cross-sectional representative surveys, the German National Food Consumption Study (Nationale Verzehrsstudie, NVS) from 1985-8 and the nutrition module 'EsKiMo' of the German Health Interview and Examination Survey for Children and Adolescents (KiGGS) from 2006, were analysed for differences in food and nutrient intakes stratified by age and sex groups.

Setting: Secondary analyses of data from representative observational studies.

Subjects: Children and adolescents aged 6-17 years living in Germany in the 1980s ( $n$ 2265) and in 2006 ( $n$ 2506).

Results: Food consumption was characterised by higher amounts of vegetables/ pulses, fruits/nuts and beverages and less meat products/sausages, butter, fats/oils, potatoes/potato products and bread/pastries in 2006 than in 1985-8. The overall changes in food intake were reflected in improvements of macronutrient composition, increased water intake and lower energy density of the diet. Intake of most vitamins and minerals increased in relation to energy intake, but the nutrient density of the diet for vitamins $\mathrm{B}_{12}$ and $\mathrm{D}$ decreased. The most critical nutrients observed in NVS and EsKiMo were folate, vitamin D, vitamin A, vitamin $\mathrm{E}, \mathrm{Ca}$ and $\mathrm{Fe}$. In addition, dietary fibre intake was relatively low and fatty acid and carbohydrate compositions were not favourable.

Conclusions: Further efforts will be necessary to improve dietary habits among children and adolescents.
\end{abstract}

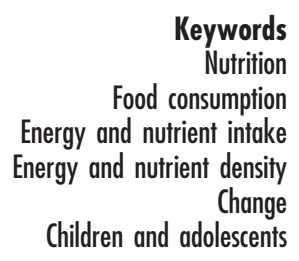

Keywords

Nutrition

Energy and nutrient intake

Children and adolescents
During the past two decades, various and complex economic, technological and social changes have occurred in the living conditions of children and adolescents. Several of these developments are likely to have a significant impact on behavioural changes. From the perspective of prevention and health promotion, health behaviour and its change over the years during childhood and adolescence are of special interest. Besides physical activity and social integration, health behaviour includes also dietary behaviour, which has an essential impact on development and well-being in general, as well as on development of overweight and obesity in children and adolescents. In the long term, nutrition in childhood and adolescence has a potential impact on adult morbidity and mortality ${ }^{(1,2)}$.

Changes which may have affected the dietary habits of children and adolescents are, for example, enlargement of the variety of available foods (e.g. fortified foods, energy-dense fast foods and soft drinks), eating and cooking habits at home, time spent on personal computers, video games and Internet use, commercial advertising and consumer information. For about two decades it could only be assumed that changes observed in other industrial nations were similar for Germany, because the most recent representative German National Food Consumption Study (Nationale Verzehrsstudie, NVS), which included children and adolescents, was conducted from 1985 until 1988. The NVS II conducted in 2006 did not include children and adolescents younger than 14 years $^{(3)}$. After the NVS study, only data from small local studies could give some impression of how food consumption patterns, energy and nutrient intake had changed over time. The Dortmund Nutritional and Anthropometric Longitudinally Designed (DONALD) study is the only study that has been providing long-term food and nutrient intake data of children and adolescents based on $3 \mathrm{~d}$ weighed dietary records in Germany since 1985. However, the sample of this study has not been intended to be representative for Germany ${ }^{(4)}$. Further food consumption data come from household budget surveys (Einkommens- und Verbrauchsstichprobe, EVS). These studies have obtained 
information from household booklets for expenses on foods and beverages. The approximations of individual information from household data have limited validity, especially for children and adolescents ${ }^{(5)}$. The nationally representative Eating study as a KiGGS Module (EsKiMo) gives up-to-date insight into the food intake of children and adolescents and provides the opportunity to observe changes which have occurred during the last 20 years.

The current paper presents the findings of NVS and EsKiMo, revealing improvements in dietary habits and nutrient intakes and information for preventive measures.

\section{Subjects and methods}

The first German National Food Consumption Study (NVS) was conducted between 1985 and 1988 in the Federal Republic of Germany and West Berlin. It was funded by the Federal Ministry for Research and Technology. Sampling of private households was performed stratified and disproportionately by means of a defined random procedure. All persons living permanently in the selected households were asked to participate. The NVS sample included data from 1066 children aged 6-11 years and 1199 adolescents aged 12-17 years (1111 boys and 1154 girls). The food intake was assessed with $7 \mathrm{~d}$ dietary records. Amounts of foods were in general obtained by weighing and, if this was not possible outside the home, portion sizes were estimated using household measurements (e.g. cup, teaspoon). The total participation rate of NVS was $74 \%$; the participation rate of children and adolescents is not reported ${ }^{(6,7)}$.

In 2006, the dietary behaviour of 6- to 17-year-olds was assessed in a module of the German Health Interview and Examination Survey for Children and Adolescents (KiGGS $)^{(8)}$. KiGGS was conducted by the Robert Koch Institute with the aim to collect comprehensive and nationwide data on the health status of children and adolescents from May 2003 to May 2006. The sample was drawn with a two-stage clustered and stratified sampling procedure. In the first stage, 167 sample points representative for German communities were selected with regard to community size and federal state. In the second stage, for every age, almost the same number of participants was randomly selected from the population registries. The overall response rate was $67 \%$. A total of 17641 children and adolescents aged 0 to 17 years were examined $^{(9)}$. The Eating study as a KiGGS Module (EsKiMo) was performed by the Robert Koch Institute and the University of Paderborn, funded by the Federal Ministry of Food, Agriculture and Consumer Protection. For EsKiMo, an age-stratified random sub-sample of KiGGS participants was comprehensively asked about their food intake from January to December 2006. Data of 1234 children aged 6-11 years and 1272 adolescents aged 12-17 years were obtained (1248 boys and 1258 girls).
The participation rate of EsKiMo was 63\%. As children and adolescents differ in their abilities, willingness to cooperate and personal circumstances, two different tools for data collection were used. Parents of participants younger than 12 years were asked to complete dietary records on three given consecutive days. Participants 12 years of age and older were personally interviewed about their food intake during the last four weeks following a modified diet history method with the use of the DISHES (Dietary Interview Software for Health Examination Studies) software ${ }^{(10)}$. Portion sizes were identified in EsKiMo using tableware models and a German picture book adapted from the EPIC-SOFT Picture Book ${ }^{(11)}$, packaging size and household measurements, or sometimes by weighing. Furthermore, all participants were asked about their sociodemographic background, leisure-time activities, lunch at school, body weight and height. As an incentive, all participants received $€ 5$ per recorded day and $€ 10$ per interview ${ }^{(10)}$.

\section{Food composition database}

All foods were aggregated as consumed to food groups according to the classification system used in the NVS. Similar groups were summarised (e.g. confectionery/jam/ sugar, alcoholic beverages). Food intake data were converted to average daily energy and nutrient intakes using the German Nutrient Database (Bundeslebensmittelschlüssel, BLS; Max Rubner Institut, Karlsruhe, Germany). The BLS essentially covers average nutritional values of approximately 10000 food codes available on the German market (fresh foods, processed foods and dishes). The nutrient calculation in the NVS dataset was performed with the BLS version II. $2^{(5)}$ and the EsKiMo data with the BLS version II.3, which may be assumed to reflect the food composition at the time of the surveys best. In these two versions of the BLS, branded foods and fortified foods are not included. Therefore, the food compositions of about 1200 foods, mainly sweets, cereals and fast foods, were collected from producer information, Internet queries, labels and information from additional food composition databases from other countries as completion of the EsKiMo nutrient database. Furthermore a database of supplements was appended ${ }^{(10)}$, which was developed for the NVS II ${ }^{(3)}$. Thus, in EsKiMo nutrient intake includes intakes from fortified foods and dietary supplements. For the calculation of total folate, amounts of folic acid in fortified foods and supplements were multiplied by 1.7 because of the higher bioavailability of synthetic folic acid compared with natural folate ${ }^{(12)}$.

\section{Statistical analyses}

All analyses were performed with the SPSS statistical software package version $14 \cdot 0$ (SPSS Inc., Chicago, IL, USA). Descriptive statistics (percentiles 25, 50 and 75) summarise the data. The Mann-Whitney $U$ test was used to test differences in the distributions of food and nutrient intakes between the years 1985-8 and 2006, taking 
statistical significance as $P<0 \cdot 05$. The analyses were done separately for children, adolescents, boys and girls.

In EsKiMo, all cases were weighed by a weighting factor which corrects for the disproportionally higher number of participants from the eastern parts of Germany, differences in the age, sex and nationality distribution of the final sample and the general population, and takes the day of the week of the records into account ${ }^{(9,10)}$.

Energy density was calculated by dividing the energy content of the diet by the weight of the diet $(\mathrm{kJ} / \mathrm{g})$. Energy density of foods (without beverages) could be calculated exactly only with the data of EsKiMo. For NVS, the sugar content of beverages (except water, tea and coffee) was estimated at 10\% (40 kcal $(167 \mathrm{~kJ}) / 100 \mathrm{~g})$. Nutrient densities were calculated as nutrient intake (g, mg or $\mu \mathrm{g}$ ) per unit of energy (MJ).

\section{Results}

\section{Food consumption}

Table 1 and Table 2 show the food intake by main food categories among children and adolescents. There are distinct differences for total reported food intake among adolescents between EsKiMo and NVS, with larger quantities in EsKiMo. A slightly higher food intake in EsKiMo than in NVS can be noticed among 6- to 11-year-old girls, but not among boys. Beverage intake, however, was notably higher in all age and sex groups in 2006 than 20 years ago. Differences between food intake in the 1980s and 2006 exist for all food groups, although they are not significant in all age and sex groups. Both children and adolescents ate less bread/ pastries, meat, meat products/sausages (NS among 12-17year-old boys), eggs (NS among 12-17-year-old boys), butter, potatoes/potato products and tea/coffee in 2006. In contrast, the consumed amounts of pasta/rice/cereals, cheese (NS among 6-11-year-old boys), vegetables/pulses, fruits/nuts, confectionery/jam/sugar, condiments/sauces and non-alcoholic beverages were higher than 20 years ago. Decreased intakes in the group of children but increased intakes among adolescents occurred for fish/fish products (NS among 6-11-year-old boys), milk/dairy products (NS among 12-17-year-old boys), fats/oils (NS among 12-17year-old girls) and alcoholic beverages.

\section{Energy and nutrient intakes}

Table 3 and Table 4 show the energy and nutrient intakes of children and adolescents in 1985-8 and 2006. Notable differences between the two surveys exist with respect to energy and most macro- and micronutrients, which are in tendency similar for children and adolescents. Fat intake decreased significantly (NS among 12-17-year-old boys) due to declines of both saturated and unsaturated fatty acids among children and due to reduction of only unsaturated fatty acids among adolescents. Protein intake decreased among children but increased among adolescents (NS among 12-17-year-old girls). Carbohydrate intake increased in all age and sex groups except 6- to 11-year-old boys due to higher polysaccharide intake and additionally, among adolescents, because of increased mono- and disaccharide intake. Only in adolescents was consumption of dietary fibre significantly higher in 2006 than in 1985-8. The lower fat intake and higher carbohydrate intake resulted in a lower percentage of energy from fat and a higher percentage of

Table 1 Distribution of average daily food intakes among 6- to 11-year-old German boys and girls in 1985-8 and 2006

\begin{tabular}{|c|c|c|c|c|c|c|c|c|c|c|c|c|c|c|}
\hline \multirow[b]{3}{*}{ Food intake (g/d) } & \multicolumn{7}{|c|}{ 6- to 11-year-old boys } & \multicolumn{7}{|c|}{ 6- to 11-year-old girls } \\
\hline & \multicolumn{3}{|c|}{ NVS 1985-8 } & \multicolumn{3}{|c|}{ EsKiMo 2006} & \multirow[b]{2}{*}{$P$} & \multicolumn{3}{|c|}{ NVS 1985-8 } & \multicolumn{3}{|c|}{ EsKiMo 2006} & \multirow[b]{2}{*}{$P$} \\
\hline & P25 & P50 & P75 & P25 & P50 & P75 & & P25 & P50 & P75 & P25 & P50 & P75 & \\
\hline Total food (except beverages) & 871 & 1077 & 1281 & 917 & 1071 & 1274 & 0.913 & 817 & 966 & 1155 & 869 & 1019 & 1179 & 0.015 \\
\hline Total beverages & 373 & 543 & 750 & 700 & 921 & 1167 & $<0.001$ & 354 & 516 & 695 & 633 & 830 & 1101 & $<0.001$ \\
\hline Bread/pastries & 124 & 163 & 212 & 100 & 140 & 188 & $<0.001$ & 108 & 148 & 193 & 92 & 129 & 174 & $<0.001$ \\
\hline Pasta/rice/cereals & 23 & 42 & 66 & 57 & 88 & 139 & $<0.001$ & 18 & 35 & 54 & 54 & 88 & 124 & $<0.001$ \\
\hline Meat & 29 & 49 & 73 & 15 & 32 & 55 & $<0.001$ & 25 & 44 & 66 & 10 & 27 & 52 & $<0.001$ \\
\hline Meat products/sausages & 31 & 51 & 79 & 16 & 35 & 62 & $<0.001$ & 25 & 41 & 66 & 11 & 29 & 55 & $<0.001$ \\
\hline Fish/fish products & 0 & 0 & 16 & 0 & 0 & 19 & 0.135 & 0 & 0 & 14 & 0 & 0 & 18 & 0.008 \\
\hline Eggs & 12 & 22 & 34 & 1 & 10 & 23 & $<0.001$ & 11 & 20 & 31 & 0 & 7 & 22 & $<0.001$ \\
\hline Milk/dairy products & 190 & 301 & 455 & 155 & 260 & 388 & $<0.001$ & 170 & 278 & 420 & 121 & 224 & 333 & $<0.001$ \\
\hline Cheese & 4 & 14 & 29 & 5 & 17 & 39 & 0.050 & 4 & 13 & 26 & 5 & 17 & 38 & $<0.001$ \\
\hline Butter & 4 & 11 & 21 & 0 & 3 & 8 & $<0.001$ & 3 & 10 & 19 & 0 & 3 & 8 & $<0.001$ \\
\hline Fats/oils & 8 & 12 & 20 & 4 & 8 & 13 & $<0.001$ & 7 & 11 & 18 & 3 & 7 & 11 & $<0.001$ \\
\hline Potatoes/potato & 47 & 73 & 111 & 23 & 49 & 83 & $<0.001$ & 45 & 69 & 106 & 22 & 50 & 79 & $<0.001$ \\
\hline Vegetables/pulses & 48 & 78 & 116 & 51 & 87 & 139 & 0.002 & 47 & 74 & 109 & 51 & 96 & 155 & $<0.001$ \\
\hline Fruits/nuts & 43 & 93 & 158 & 57 & 113 & 183 & 0.001 & 46 & 93 & 154 & 57 & 125 & 208 & $<0.001$ \\
\hline Confectionery/jam/sugar & 29 & 49 & 72 & 33 & 61 & 97 & $<0.001$ & 25 & 44 & 70 & 32 & 56 & 88 & $<0.001$ \\
\hline Condiments/sauces & 3 & 6 & 11 & 14 & 33 & 80 & $<0.001$ & 3 & 6 & 9 & 15 & 32 & 74 & $<0.001$ \\
\hline Non-alcoholic beverages & 320 & 485 & 682 & 683 & 917 & 1148 & $<0.001$ & 289 & 470 & 640 & 627 & 817 & 1100 & $<0.001$ \\
\hline Tea/coffee & 0 & 0 & 56 & 0 & 0 & 0 & $<0.001$ & 0 & 0 & 66 & 0 & 0 & 0 & $<0.001$ \\
\hline Alcoholic beverages & 0 & 0 & 1 & 0 & 0 & 0 & $<0.001$ & 0 & 0 & 1 & 0 & 0 & 0 & $<0.001$ \\
\hline
\end{tabular}

NVS, German National Food Consumption Study; EsKiMo, Eating study as a KiGGS Module; KiGGS, German Health Interview and Examination Survey for Children and Adolescents; P25, 25th percentile; P50, 50th percentile; P75, 75th percentile. 
Table 2 Distribution of average daily food intakes among 12- to 17-year-old German boys and girls in 1985-8 and 2006

\begin{tabular}{|c|c|c|c|c|c|c|c|c|c|c|c|c|c|c|}
\hline \multirow[b]{3}{*}{ Food intake $(\mathrm{g} / \mathrm{d})$} & \multicolumn{7}{|c|}{ 12- to 17 -year-old boys } & \multicolumn{7}{|c|}{ 12- to 17 -year-old girls } \\
\hline & \multicolumn{3}{|c|}{ NVS 1985-8 } & \multicolumn{3}{|c|}{ EsKiMo 2006} & \multirow[b]{2}{*}{$P$} & \multicolumn{3}{|c|}{ NVS 1985-8 } & \multicolumn{3}{|c|}{ EsKiMo 2006} & \multirow[b]{2}{*}{$P$} \\
\hline & P25 & P50 & P75 & P25 & P50 & P75 & & P25 & P50 & P75 & P25 & P50 & P75 & \\
\hline Total food (except beverages) & 1025 & 1241 & 1554 & 1250 & 1603 & 2053 & $<0.001$ & 821 & 1019 & 1231 & 1029 & 1373 & 1697 & $<0.001$ \\
\hline Total beverages & 508 & 730 & 1107 & 1382 & 1919 & 2617 & $<0.001$ & 454 & 643 & 863 & 1231 & 1630 & 2246 & $<0.001$ \\
\hline Bread/pastries & 162 & 218 & 297 & 137 & 190 & 268 & $<0.001$ & 127 & 172 & 227 & 116 & 154 & 206 & $<0.001$ \\
\hline Pasta/rice/cereals & 24 & 43 & 67 & 93 & 142 & 200 & $<0.001$ & 20 & 33 & 54 & 63 & 108 & 165 & $<0.001$ \\
\hline Meat & 53 & 80 & 109 & 43 & 69 & 106 & 0.001 & 43 & 66 & 92 & 24 & 40 & 63 & $<0.001$ \\
\hline Meat products/sausages & 45 & 75 & 114 & 40 & 71 & 114 & $0 \cdot 291$ & 29 & 50 & 80 & 20 & 40 & 65 & $<0.001$ \\
\hline Fish/fish products & 0 & 0 & 21 & 0 & 7 & 15 & 0.002 & 0 & 0 & 17 & 0 & 5 & 13 & $<0.001$ \\
\hline Eggs & 14 & 24 & 38 & 13 & 22 & 36 & $0 \cdot 122$ & 11 & 21 & 34 & 9 & 16 & 25 & $<0.001$ \\
\hline Milk/dairy products & 161 & 281 & 457 & 168 & 305 & 500 & 0.081 & 92 & 199 & 313 & 116 & 235 & 390 & $<0.001$ \\
\hline Cheese & 7 & 20 & 40 & 15 & 28 & 48 & $<0.001$ & 8 & 18 & 35 & 15 & 29 & 47 & $<0.001$ \\
\hline Butter & 6 & 16 & 30 & 4 & 10 & 24 & $<0.001$ & 3 & 10 & 20 & 3 & 7 & 16 & $<0.001$ \\
\hline Fats/oils & 11 & 17 & 28 & 12 & 20 & 34 & $<0.001$ & 10 & 15 & 22 & 9 & 16 & 25 & $0 \cdot 286$ \\
\hline Potatoes/potato products & 67 & 99 & 151 & 55 & 93 & 138 & 0.002 & 50 & 86 & 126 & 44 & 73 & 114 & 0.003 \\
\hline Vegetables/pulses & 73 & 104 & 152 & 101 & 169 & 272 & $<0.001$ & 62 & 100 & 152 & 109 & 180 & 302 & $<0.001$ \\
\hline Fruits/nuts & 27 & 73 & 139 & 60 & 132 & 231 & $<0.001$ & 37 & 93 & 162 & 84 & 161 & 282 & $<0.001$ \\
\hline Confectionery/s & 30 & 53 & 86 & 41 & 66 & 109 & $<0.001$ & 22 & 42 & 66 & 33 & 56 & 89 & $<0.001$ \\
\hline Condiments/sauces & 4 & 8 & 13 & 43 & 67 & 110 & $<0.001$ & 3 & 6 & 11 & 35 & 56 & 87 & $<0.001$ \\
\hline pholic beverages & 350 & 561 & 862 & 1334 & 1786 & 2415 & $<0.001$ & 313 & 486 & 705 & 1149 & 1554 & 2130 & $<0.001$ \\
\hline Tea/coffee & 0 & 60 & 191 & 0 & 0 & 21 & $<0.001$ & 0 & 80 & 180 & 0 & 0 & 43 & $<0.001$ \\
\hline Alcoholic beverages & 0 & 0 & 29 & 0 & 3 & 101 & $<0.001$ & 0 & 0 & 5 & 0 & 2 & 24 & $<0.001$ \\
\hline
\end{tabular}

NVS, German National Food Consumption Study; EsKiMo, Eating study as a KiGGS Module; KiGGS, German Health Interview and Examination Survey for Children and Adolescents; P25, 25th percentile; P50, 50th percentile; P75, 75th percentile.

energy from carbohydrate in the diet. Protein as a proportion of total energy intake did not change significantly among children, but decreased among adolescents. Total energy intake was lower among children, but higher among adolescents in 2006 than in the previous years. Water intake increased in all age and sex groups. Intake of vitamin $\mathrm{D}$ was lower in all age and sex groups, while intake of vitamin $\mathrm{E}$ was higher among adolescents, but not among children, in 2006 than in 1985-8. Vitamin A intake fell among children but increased among adolescents, whereas $\beta$-carotene intake increased among both children and adolescents. In 2006, the intakes of all watersoluble vitamins apart from vitamin $\mathrm{B}_{12}$ were higher compared with the 1980s, although not always significant among children. The intakes of the minerals $\mathrm{Ca}$ and $\mathrm{Mg}$ increased in all groups; the intakes of $\mathrm{K}, \mathrm{P}, \mathrm{Fe}$ and $\mathrm{Zn}$ increased among adolescents but decreased or did not change among children.

In 2006, energy density was significantly lower in all age and sex groups than 20 years ago, but nutrient density of the diet increased for both dietary fibre and most micronutrients (Table 5 and Table 6). The densities of vitamin $B_{1}$, vitamin $B_{2}$, vitamin $B_{6}$, folate, niacin and vitamin $C$ increased whereas the densities of vitamin $B_{12}$ (NS among 6-11-year-old boys) and vitamin D decreased among both children and adolescents. $\beta$-Carotene density became higher in all age and sex groups, whereas total vitamin A density increased only among adolescents but decreased among children. Nutrient densities of K, Ca, Mg, P (NS among 12-17-year-old boys) and Fe increased, but density of $\mathrm{Zn}$ did not change.

\section{Discussion}

Between the years 1985-8 and 2006, food consumption and nutrient intakes of children and adolescents changed considerably. On the one hand, positive changes were, for example, increases of vegetables/pulses, fruits/nuts and non-alcoholic beverage consumption and decreased consumption of meat products/sausages, butter and fats/ oils. On the other hand, the decreased consumption of potatoes/potato products and bread/pastries was undesirable. The macronutrient composition of the diet improved, the micronutrient content of the diet in relation to energy intake increased and the energy density became lower. However, some micronutrients were not supplied sufficiently, fibre intake was relatively low, and fatty acid and carbohydrate compositions were unfavourable in both the 1980s and 2006.

Before discussing the implications of the results, some limitations of the analyses have to be considered. Areas and populations differ between the two nationwide surveys NVS (1985-8) and EsKiMo (2006). NVS was conducted before the German reunification and covered only the western part of Germany. EsKiMo, however, was conducted in both the western and the eastern part of Germany. Analyses of the National Health Surveys conducted in 1991 and in 1998 indicated that differences in food intake between adults from eastern and western parts of Germany existed in 1998, although these differences were smaller than those observed one year after the reunification ${ }^{(13)}$. It might be suspected that the results of the present analyses were affected by including children 


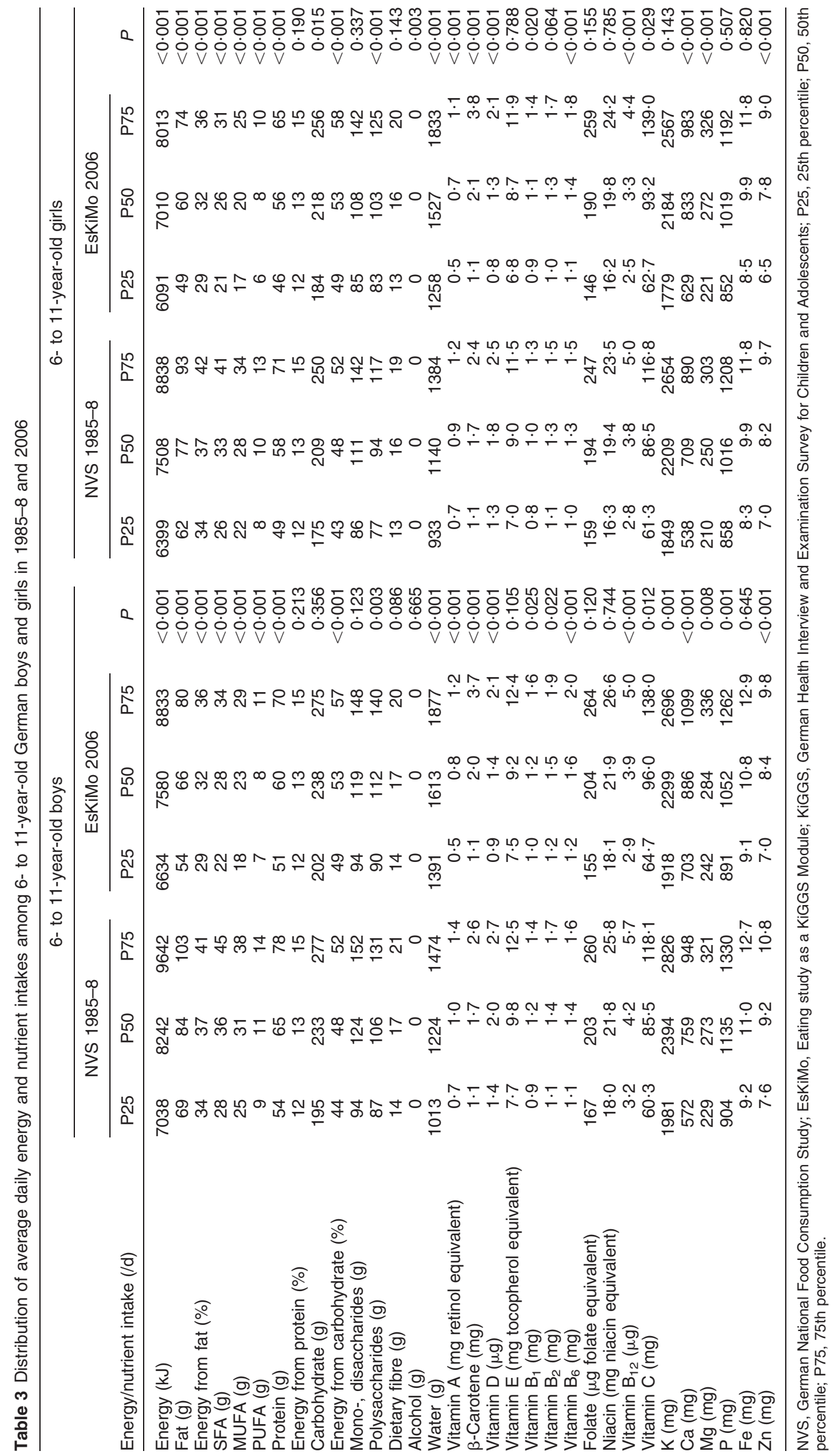




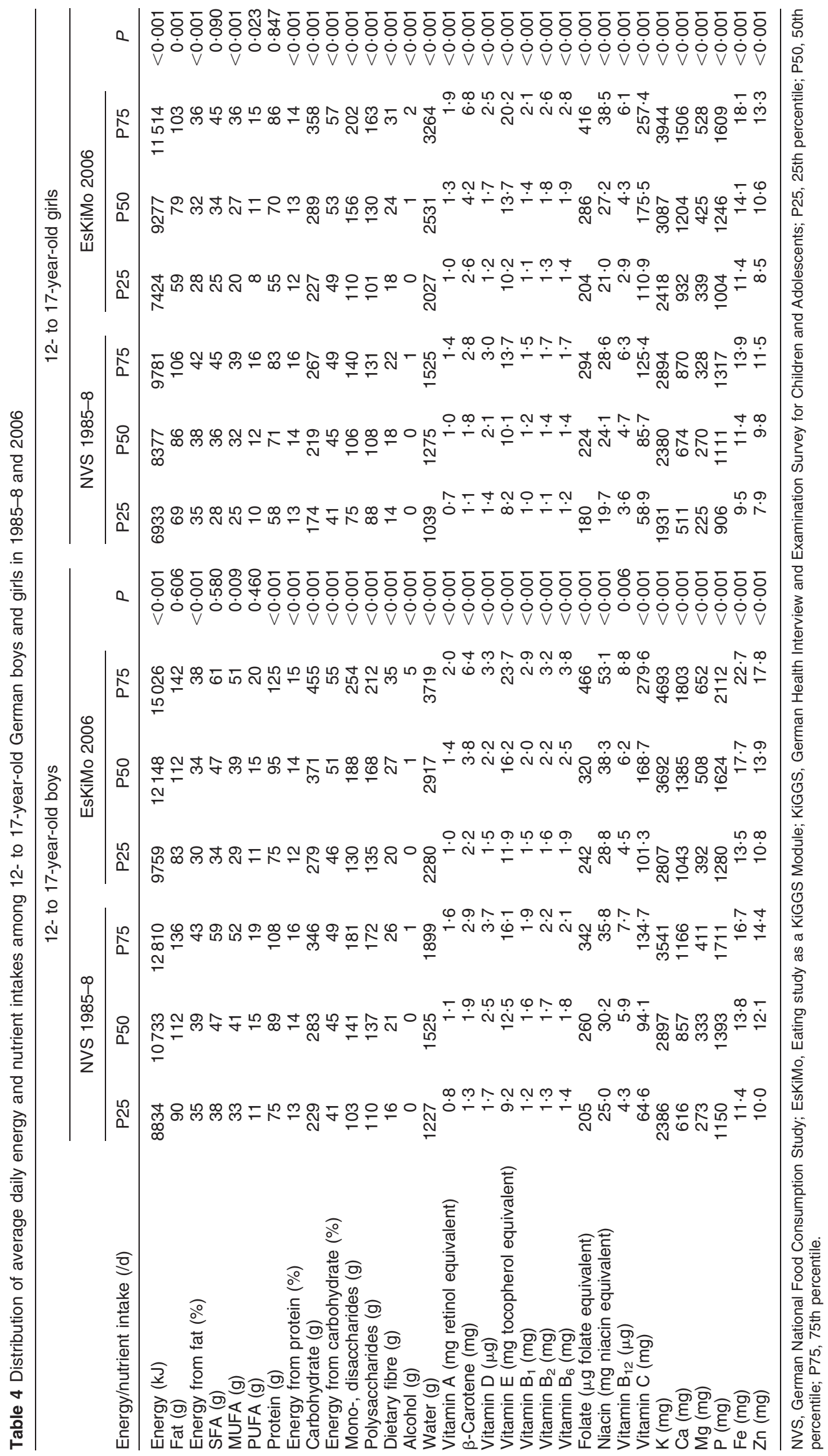




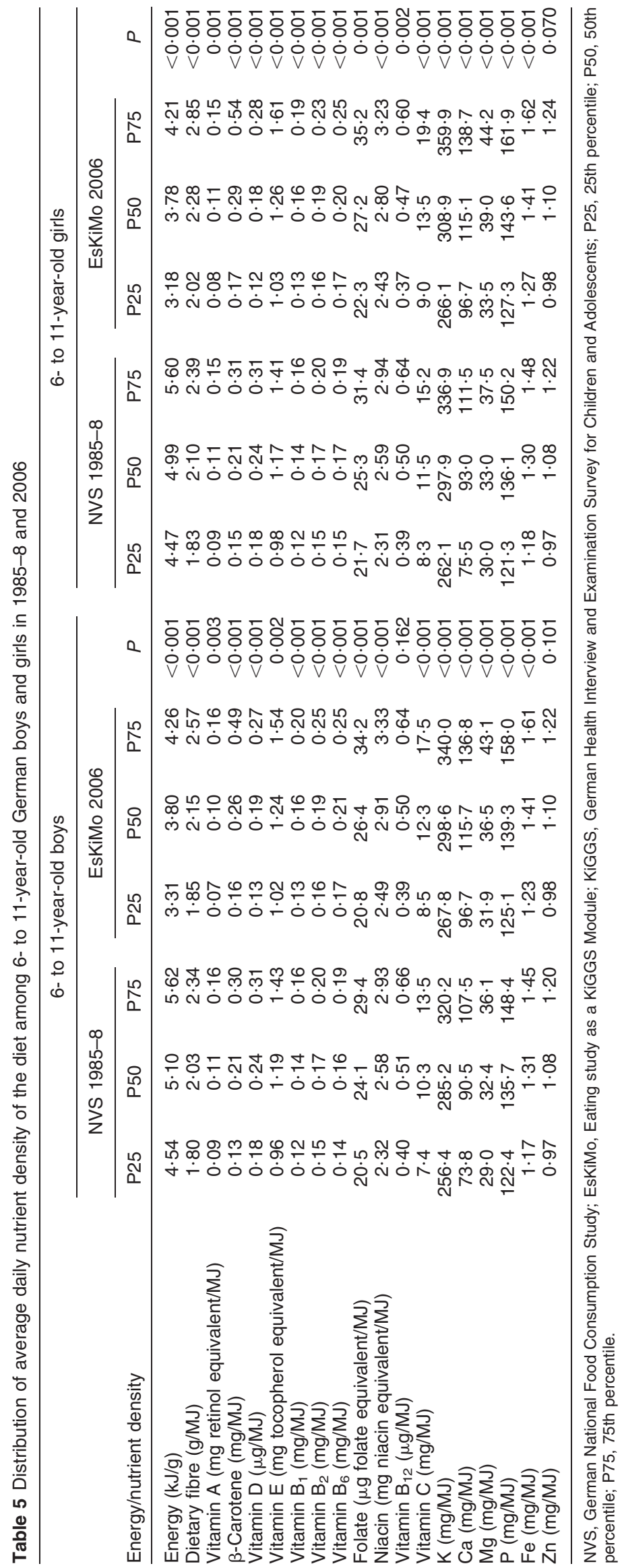




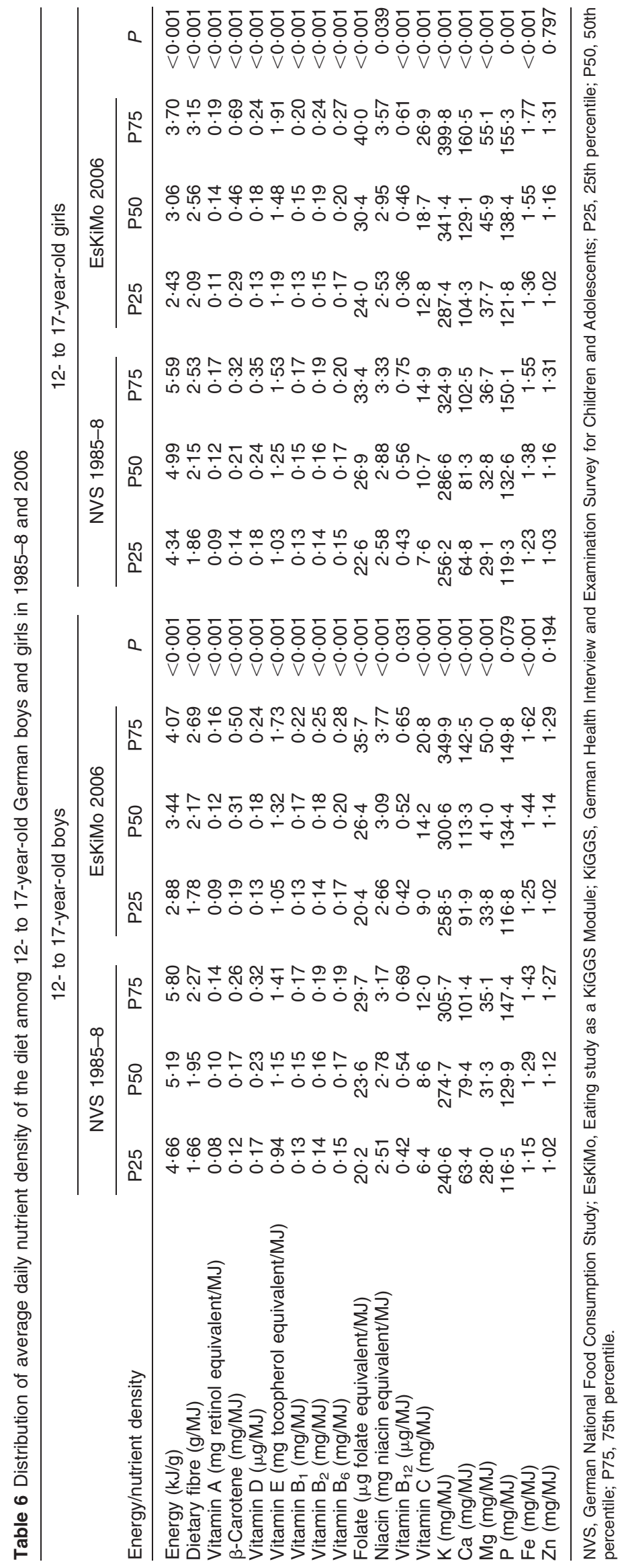


and adolescents from the newly formed German states. However, including only children from the western parts of Germany in the analyses (implies both same area and similar survey technique) resulted in analogous findings. The only differences were that the increases in cheese intake and nutrient density of $\mathrm{Zn}$ became significant among boys.

Another difference between the two surveys, which should be taken into account, is the selection criteria. The NVS sample consists of households with German citizenship householders, but in the EsKiMo study, a representative sample including migrants with both German and non-German nationality was aspired. In both surveys, sufficient German language skills were necessary.

An additional point is that several methods for collecting data on food consumption are available. Crucial to the particular decision for a method are theoretical and practical considerations. General aims are to maximise motivation and participation among the sample and to minimise burden and errors of data collection with the given resources. Beyond doubt, conditions among the population on the one hand and scientific and technical resources on the other hand have changed a lot during the past two decades. Hence, it is perspicuous that NVS and EsKiMo used different methods for data collection. An advantage, but also a limitation of EsKiMo is the fact that the special needs of children and adolescents were met. The estimated $3 \mathrm{~d}$ record, which was conducted by the children and their parents in EsKiMo, was methodologically comparatively similar to the weighed $7 \mathrm{~d}$ record of the NVS. Although dietary records are often regarded as the gold standard ${ }^{(14)}$, they may interfere with eating habits and are prone to under-reporting, especially in obese subjects and adolescents ${ }^{(15)}$. In contrast, assessing the food intake of adolescents with the DISHES software might be associated with difficulties in remembering and misreporting. DISHES has been validated for adults aged 19-59 years, but not yet for adolescents ${ }^{(16)}$. A high ratio of compliance in EsKiMo was observed including few discarded reports and interviews because of doubtful validity and relatively low number of low energy reporters. Low energy reporters were not excluded because that would reduce the representativeness of the total samples. Cut-offs for the identification of high energy reporters were not applied. A separate validation survey for this age group was not performed either in NVS or in EsKiMo. In addition, different periods of data collection ( $7 \mathrm{~d} v .3 \mathrm{~d}$ and 4 weeks) should also be considered when interpreting the results, especially for seldom consumed foods like fish.

The data sets of NVS and EsKiMo were based upon different versions of the German Nutrient Database. Principally, it is difficult to differentiate between real changes in nutrient intake because of altered dietary behaviour and nutrient contents of food and feigned changes because of different databases when regarding changes over time. Within the GISELA Study, a study with German senior citizens, the effects of the BLS versions II.2 and II.3 on energy and nutrient calculation were analysed. The results indicated that nearly all variables differed marginally but significantly between the two databases. For example, calculated energy intake with BLS II.3 was about $1 \%$ lower than when calculated with BLS II.2. Small positive deviations were calculated for carbohydrate and protein intakes (about $+1 \%$ difference), whereas the deviation was negative for fat intake (about $-6 \%$ difference). The amounts of most micronutrients were slightly different when calculated with the more recent version, except vitamin $\mathrm{D}$, which differed notably by about $-19 \%$ among women and $-36 \%$ among men ${ }^{(17)}$. Thus, the changes in macro- and micronutrient intake observed herein can be attributed only to a very small extent to the different nutrient database versions. The decrease of vitamin $\mathrm{D}$ intake, however, might be to some extent artificial.

\section{Food consumption}

Although it is necessary to discuss the data with some caution, they provide basic and relevant information.

The comparison of food consumption among children and adolescents in Germany in 1985-8 and 2006 revealed significant changes. During the past two decades, total food intake increased and food selection altered. The amounts consumed of pasta/rice/cereals, cheese, vegetables/pulses, fruits/nuts, confectionery/jam/sugar, condiments/sauces and non-alcoholic beverages increased significantly. Consumption of bread/pastries, meat, meat products/sausages, eggs, butter, potatoes/potato products and tea/coffee decreased in contrast. Intakes of both fats/ oils and milk/dairy products decreased significantly among children, but fats/oils increased among adolescent boys and milk/dairy products increased among adolescent girls. Despite mainly improved food selection, more plant foods but less animal, high-fat and high-sugar foods should be consumed to meet the German recommendations for food intake ${ }^{(18)}$. In addition, beverage selection should be optimised, because energy-supplying juices and sugar-sweetened drinks (soft drinks) accounted for about half the beverages (data not shown). Because of the clear associations of soft drink consumption and nutrition and health outcomes, especially overweight and obesity $^{(19-21)}$, consumption of these beverages should be replaced by energy-free beverages. The main results are to some extent in accordance with findings of studies from Germany and other European countries and the USA, despite different periods and methods of data collection and evaluation (food classification, age groups). The German DONALD study found significant positive trends for beverage consumption in all age and sex groups, bread/cereals among 9- to 13-year-old boys and 4- to 8-year-old girls, and negative trends for both meat/ fish/eggs and fats/oils among 4- to 18-year-old boys and 
4- to 13-year-old girls and for fruits/vegetables among 4- to 8-year-old boys and 9- to 13-year-old girls, between 1985 and 2000. The consumption of milk/milk products, potatoes/ pasta/rice and candy/cakes did not change significantly ${ }^{(22)}$. In addition, fortified foods became more important for child nutrition $^{(23)}$. The Bogalusa Heart Study revealed lower consumption of breads/grains, mixed meats, eggs, fats/oils, vegetables/soups, desserts and candy, but higher consumption of cheese, fruits/juices, beverages, snacks, condiments and poultry, among 10-year-olds in 1992-4 compared with 1973-4. The consumption of seafood, beef, pork and milk did not change ${ }^{(24)}$. Other studies from the USA indicated an increase of beverage intake among 2- to 18-year-olds ${ }^{(25)}$ and among 11- to 18-year-olds an increase of vegetable consumption and a decline of milk consumption $^{(26)}$. The Nationwide Nutritional Survey of Food Behaviour of the Italian population (INN-CA) conducted in 1980-4 and 1994-6 observed increasing amounts of cakes/ biscuits/pastries, ham/salami and savoury snacks among Italian children (1- to 9-year-olds) and adolescents (10- to 17 -year-olds) ${ }^{(27)}$.

\section{Energy and nutrient intakes}

The overall changes of food intake were reflected in improvements of nutrient intakes. In 2006 most D-A-CH reference values ${ }^{(28)}$ were met better than in the 1980 s. First, water intake increased in all age and sex groups; thus the median water intake of children nearly reached the dietary recommendations and adolescents met the recommendations for water intake. The recommended intake of carbohydrates (>50\% energy) was not met in median in any group in the 1980 s, but reached the median in all age and sex groups in 2006. Although the intake of polysaccharides increased, mono- and disaccharides accounted still for half of total carbohydrate intake. In contrast, the intake of dietary fibre was also relatively low $(2.4 \mathrm{~g} / \mathrm{MJ}$ recommended). Therefore, the intake of complex carbohydrates and dietary fibre needs increasing further. The recommended fat intake (30-35\% energy for 6- to 14-year-olds, $<30 \%$ energy for $\geq 15$-yearolds) was exceeded by far in all groups in the 1980s. In 2006, median fat intake was higher than recommended only among 15 - to 17 -year-olds (data not shown). Even though the intake of SFA fell in all groups, in comparison to the D-A-CH reference value (saturated:unsaturated fatty acids $=1: 2$ ) their proportion was still rather high in 2006. Further improvement of the fatty acid composition is necessary. Median protein intake was much higher than the recommendations in all groups (between $17 \mathrm{~g} / \mathrm{d}$ and $60 \mathrm{~g} / \mathrm{d}$ depending on age and sex recommended), thus nearly all children and adolescents ingested more protein than adequate. Other studies indicate similar changes of macronutrient intake. Trend analyses with data of the DONALD study came to the result that overall fat intake, SFA and MUFA intakes of the subjects decreased, whereas carbohydrate intake increased between 1985 and
$2000^{(22)}$. As evaluations of the Bogalusa Heart Study indicate, trends in total fat, SFA and MUFA and percentage of energy from fat were negative among 10-year-old children between 1984-5 and 1992-4. Total carbohydrate intake and percentage of energy from carbohydrates remained similar $^{(24)}$. Results of the Continuing Survey of Food Intake by Individuals (CSFII) showed a decline in percentage of energy from fat and protein which was compensated by an increase in carbohydrate intake among 11- to 18year-olds $^{(26)}$. In Northumbrian 11- to 12-year-olds, the percentage of energy from fat also decreased between 1980 and 2000, alongside an increase in percentage of energy from starch, but not from sugars ${ }^{(29,30)}$.

The present results indicate that energy intake was lower among children, but higher among adolescents in 2006 compared with 1985-8. On the one hand, this may be due to misreporting as discussed before. On the other hand, the observation may be explained by changed physical activity and body height and weight. Comparable studies support the finding that energy intake develops differently among children and adolescents. Among boys of the DONALD study energy intake decreased slightly, albeit significant only in the group of 14- to 18-year-olds. Among girls energy intake had a negative trend for 4- to 8-year-olds and a positive trend for 9- to 18-year-olds, however not significant ${ }^{(22)}$. In the third National Health and Nutrition Examination Survey in the USA (NHANES III, 1988-94) energy intake of 6- to 11-year-old children remained stable, but increased for adolescents aged 12-19 years since NHANES II (1976-80) ${ }^{(31)}$. The CSFII conducted in 1989-91 and 1994-6 among 11- to 18-year-olds came to the result that energy intake increased ${ }^{(26)}$. In contrast, energy intakes of 11- to 12-year-old boys and girls fell in Northumberland, England, between 1980 and $2000^{(29)}$.

Besides absolute energy intake, energy density is of special interest because there is convincing evidence that energy-dense foods promote the development of overweight and obesity ${ }^{(19,32)}$. Consuming nutrient-dense foods instead of energy-rich but nutrient-poor foods helps to improve the nutrient:energy ratio ${ }^{(33)}$. From this point of view, it is favourable that energy density decreased but the nutrient density of diets increased. However, in both surveys, the energy density of food (without beverages) was relatively high compared with the cut-off point of $125 \mathrm{kcal}(523 \mathrm{~kJ}) / 100 \mathrm{~g}$ food of the second World Cancer Research Fund report ${ }^{(31)}$. In the $1980 \mathrm{~s}$, median energy density of food was about $170 \mathrm{kcal}$ $(711 \mathrm{~kJ}) / 100 \mathrm{~g}$ food among children, $185 \mathrm{kcal}(774 \mathrm{~kJ}) /$ $100 \mathrm{~g}$ food among adolescent boys and $179 \mathrm{kcal}(749 \mathrm{~kJ}) /$ $100 \mathrm{~g}$ food among adolescent girls. In 2006, median energy density of food in these groups was about $150 \mathrm{kcal}$ $(627 \mathrm{~kJ}) / 100 \mathrm{~g}$ food, $161 \mathrm{kcal}(673 \mathrm{~kJ}) / 100 \mathrm{~g}$ food and $144 \mathrm{kcal}(603 \mathrm{~kJ}) / 100 \mathrm{~g}$ food, respectively. Even the 25 th percentiles of energy density were above the cut-off point in all age and sex groups in NVS and EsKiMo (data not shown). 
In addition, the evaluation of the NVS and EsKiMo data revealed higher absolute intakes and higher densities of most vitamins and minerals in 2006 than in 1985-8. This is mainly due to changes in food intake and consumption of fortified foods. Among children of the DONALD study the intake of water-soluble vitamins and minerals from fortified foods increased significantly since the $1980 \mathrm{~s}^{(23)}$. In addition, the changes may be explained to a small extent by supplement intake. In EsKiMo, the inclusion of supplements slightly increased the median intakes and densities of some micronutrients (e.g. vitamins $\mathrm{E}$ and $\mathrm{C}, \mathrm{Ca}$, $\mathrm{Mg}$ ) among adolescents, but not among children (data not shown). The D-A-CH recommendations for nutrient densities of vitamin $\mathrm{B}_{6}$, vitamin $\mathrm{B}_{12}$ and $\mathrm{Zn}$ were met in all age and sex groups in NVS and EsKiMo. In contrast, folate and vitamin D densities were too low compared with the recommendations in all age and sex groups in both surveys. Among girls, the densities of Fe and Ca were lower than recommended in both surveys. The recommendations for the intakes of vitamin D and folate were not met in any age and sex group in the two surveys. In addition, the intakes of vitamin E, Ca and vitamin A (only EsKiMo) were lower than recommended during childhood. Thus, the most critical nutrients observed in NVS and EsKiMo were folate, vitamin $\mathrm{D}$, vitamin $\mathrm{A}$, vitamin $\mathrm{E}$, Ca and $\mathrm{Fe}$. In the DONALD study, vitamin C density increased linearly and nutrient density of vitamin A remained constant between 1986 and 2001. Vitamin E intake increased from 1986 to 1993 and decreased afterwards ${ }^{(34)}$. In the US CSFII, Fe intake was higher in 1994-6 than in 1989-91, while vitamin $\mathrm{A}$ and $\mathrm{C}$, folate, $\mathrm{Ca}$ and fibre remained the same ${ }^{(26)}$. In Northumberland, vitamin $\mathrm{A}$ and $\mathrm{C}$ and $\mathrm{Fe}$ intake increased, while $\mathrm{Ca}$ intake decreased, among 11to 12-year-olds between 1980 and $1990^{(35)}$.

\section{Conclusion}

Food and nutrient intakes of German children and adolescents changed significantly during the past 20 years. Macronutrient composition and micronutrient intake improved. However, the intake of polysaccharides and dietary fibre should be enhanced and mono- and disaccharide intake should be reduced in future. In addition, the intake of folate, vitamins D, A and E, Ca and Fe have to increase to meet the recommendations. The general trend of higher micronutrient content of the diet in relation to energy intake and lower energy density should proceed. To improve the energy and nutrient density of the diet, the intake of nutritious foods with high water content should be promoted. Further efforts will be necessary to allow well-balanced diets with more plant foods and energy-free beverages, but less animal, high-fat and high-sugar foods for all children and adolescents and to stabilise enduring favourable dietary habits. The results are of interest for all involved in health policy and responsible for nutrition campaigns.

\section{Acknowledgements}

Sources of funding: The study was supported by the German Federal Ministry of Food, Agriculture and Consumer Protection. This paper was conceived and written independently of the funding agency. Conflict of interest declaration: There are no conflicts of interest. Authorship responsibilities: G.B.M.M. and H.H. designed and managed EsKiMo; C.V., A.R. and A.S. were responsible for data collection and aggregation; A.S. conducted the presented data analysis and wrote the manuscript. All co-authors contributed critical revisions and gave final approval for submission. Acknowledgements: We would like to thank PD Dr K. Gedrich, who made the dataset of the NVS available. We are also very grateful to the families whose participation was crucial and to the colleagues who supported EsKiMo.

\section{References}

1. Law M (2000) Dietary fat and adult diseases and the implications for childhood nutrition: an epidemiologic approach. Am J Clin Nutr 72, 5 Suppl., 1291S-1296S.

2. Smith GD (2007) Life-course approaches to inequalities in adult chronic disease risk. Proc Nutr Soc 66, 216-236.

3. Max Rubner-Institut (2008) Nationale Verzehrsstudie II, Ergebnisbericht Teil 2. http://www.was-esse-ich.de/ uploads/media/NVSII_Ergebnisbericht_Teil2.pdf (assessed June 2008).

4. Kroke A, Manz F, Kersting M, Remer T, Sichert-Hellert W, Alexy U \& Lentze MJ (2004) The DONALD Study. History, current status and future perspectives. Eur J Nutr 43, 45-54.

5. Gedrich K, Wagner K \& Karg G (2004) Ernährungssituation in Deutschland. In Ernäbrungsbericht 2004, pp. 21-115 [Deutsche Gesellschaft für Ernährung e.V., editor]. Bonn: DGE.

6. Kübler W, Balzter H, Grimm R, Schek A \& Schneider R (1997) National Food Consumption Survey (NVS) and Cooperative Study: Nutrition Survey and Risk Factor Analysis (VERA). Synopsis and perspectives. VERA-Schriftenreihe [W Kübler, HJ Anders and W Heeschen, series editors]. Niederkleen: Wissenschaftlicher Fachverlag Dr Fleck.

7. Adolf T, Schneider R, Eberhardt W et al. (1995) Ergebnisse der Nationalen Verzehrsstudie (1985-1988) über die Lebensmittel- und Nährstoffaufnahme in der Bundesrepublik Deutschland. VERA-Schriftenreibe [W Kübler, HJ Anders and W Heeschen, series editors]. Niederkleen: Wissenschaftlicher Fachverlag Dr Fleck.

8. Mensink GB, Bauch A, Vohmann C, Stahl A, Six J, Kohler S, Fischer J \& Heseker H (2007) EsKiMo - Das Ernährungsmodul im Kinder- und Jugendgesundheitssurvey (KiGGS). Bundesgesundheitsbl Gesundheitsforsch Gesundheitsschutz 50, 902-908.

9. Kurth BM, Kamtsiuris P, Hoelling H et al. (2008) The challenge of comprehensively mapping children's health in a nation-wide health survey: design of the German KiGGS-Study. BMC Public Health 8, 196.

10. Mensink GBM, Heseker H, Richter A, Stahl A \& Vohmann C (2007) Forschungsbericht Ernährungsstudie als KiGGSModul (EsKiMo). http://www.bmelv.de/cln_044/nn_752314/ SharedDocs/downloads/03-Ernaehrung/EsKiMoStudie.html (assessed June 2008).

11. van Kappel AL, Amoyel J, Slimani N, Vozar B \& Riboli E (1994) EPIC-SOFT Picture Book for Estimation of Food Portion Sizes. Lyon: IARC. 
12. Food and Nutrition Board \& Institute of Medicine (2000) Dietary Reference Intakes for Thiamin, Riboflavin, Niacin, Vitamin $B_{6}$, Folate, Vitamin $B_{12}$, Pantothenic Acid, Biotin, and Choline. Washington, DC: National Academy Press.

13. Mensink GBM \& Beitz R (2004) Food and nutrient intake in East and West Germany, 8 years after the reunification The German Nutrition Survey 1998. Eur J Clin Nutr 58, $1000-1010$.

14. Rockett HR \& Colditz GA (1997) Assessing diets of children and adolescents. Am J Clin Nutr 65, 4 Suppl., 1116S-1122S.

15. Livingstone MB, Robson PJ \& Wallace JM (2004) Issues in dietary intake assessment of children and adolescents. Br J Nutr 92, Suppl. 2, S213-S222.

16. Mensink GB, Haftenberger M \& Thamm M (2001) Validity of DISHES 98, a computerised dietary history interview: energy and macronutrient intake. Eur J Clin Nutr 55, 409-417.

17. Lührmann P, Kegreis I, Hartmann B, Dehne LI \& Neuhäuser-Berthold M (2002) Unterschiede in den Ergebnissen von Ernährungserhebungen in Abhängigkeit von der Verwendung der BLS-Versionen II.2 und II.3. Ernährungs Umschau 49, 296-300.

18. Kersting M, Alexy U \& Clausen K (2005) Using the concept of Food Based Dietary Guidelines to Develop an Optimized Mixed Diet (OMD) for German children and adolescents. J Pediatr Gastroenterol Nutr 40, 301-308.

19. World Health Organization (2003) Diet, Nutrition and The Prevention of Chronic Diseases. WHO Technical Report Series no. 916. Geneva: WHO.

20. James J \& Kerr D (2005) Prevention of childhood obesity by reducing soft drinks. Int J Obes (Lond) 29, Suppl. 2, S54-S57.

21. Vartanian LR, Schwartz MB \& Brownell KD (2007) Effects of soft drink consumption on nutrition and health: a systematic review and meta-analysis. Am J Public Health 97, 667-675.

22. Alexy U, Sichert-Hellert W \& Kersting M (2002) Fifteen-year time trends in energy and macronutrient intake in German children and adolescents: results of the DONALD study. $\mathrm{Br}$ J Nutr 87, 595-604.

23. Sichert-Hellert W, Kersting M, Alexy U \& Manz F (2000) Ten-year trends in vitamin and mineral intake from fortified food in German children and adolescents. Eur J Clin Nutr 54, 81-86.
24. Nicklas TA, Elkasabany A, Srinivasan SR \& Berenson G (2001) Trends in nutrient intake of 10-year-old children over two decades (1973-1994): the Bogalusa Heart Study. Am J Epidemiol 153, 969-977.

25. Nielsen SJ \& Popkin BM (2004) Changes in beverage intake between 1977 and 2001. Am J Prev Med 27, 205-210.

26. Cavadini C, Siega-Riz AM \& Popkin BM (2000) US adolescent food intake trends from 1965 to 1996. Arch Dis Child 83, 18-24.

27. Turrini A, Saba A, Perrone D, Cialfa E \& D'Amicis A (2001) Food consumption patterns in Italy: the INN-CA Study 1994-1996. Eur J Clin Nutr 55, 571-588.

28. German Nutrition Society, Austrian Nutrition Society, Swiss Society for Nutrition Research \& Swiss Nutrition Association (2002) Reference Values for Nutrient Intake. Frankfurt am Main: Umschau/Braus.

29. Fletcher ES, Rugg-Gunn AJ, Matthews JN, Hackett A, Moynihan PJ, Mathers JC \& Adamson AJ (2004) Changes over 20 years in macronutrient intake and body mass index in 11- to 12-year-old adolescents living in Northumberland. BrJ Nutr 92, 321-333.

30. Rugg-Gunn AJ, Fletcher ES, Matthews JN, Hackett AF, Moynihan PJ, Kelly S, Adams J, Mathers JC \& Adamson A (2007) Changes in consumption of sugars by English adolescents over 20 years. Public Health Nutr 10, 354-363.

31. Troiano RP, Briefel RR, Carroll MD \& Bialostosky K (2000) Energy and fat intakes of children and adolescents in the United States: data from the National Health and Nutrition Examination Surveys. Am J Clin Nutr 72, 5 Suppl., 1343S-1353S.

32. World Cancer Research Fund \& American Institution for Cancer Research (2007) Food, Nutrition, Physical Activity, and the Prevention of Cancer: A Global Perspective. Washington, DC: AICR.

33. Drewnowski A (2005) Concept of a nutritious food: toward a nutrient density score. Am J Clin Nutr 82, 721-732.

34. Alexy U, Kersting M \& Sichert-Hellert W (2003) Trends in dietary intake of vitamins $\mathrm{A}, \mathrm{C}$, and $\mathrm{E}$ in German children and adolescents - results of the DONALD Study. Int J Vitam Nutr Res 73, 335-342.

35. Adamson A, Rugg-Gunn A, Butler T, Appleton D \& Hackett A (1992) Nutritional intake, height and weight of 11-12-year-old Northumbrian children in 1990 compared with information obtained in 1980. BrJ Nutr 68, 543-563. 